\title{
LEGALITAS DAN OTORITAS FATWA DEWAN SYARIAH NASIONAL MAJELIS ULAMA INDONESIA DALAM OPERASIONAL LEMBAGA KEUANGAN SYARIAH
}

\author{
Muhamad Ibnu Afrelian ${ }^{1} \&$ Imahda Khoiri Furqon ${ }^{2}$ \\ ${ }^{1}$ Universitas Islam Negeri Sumatra Utara \\ J. IAIN No. 1 Medan Sumatra Utara \\ Email: aanafrelian@gmail.com \\ ${ }^{2}$ STAIN Jurai Siwo Metro \\ Jl. Ki Hajar Dewantara 15 A Iringmulyo Metro \\ Email: imahdaaljihat@gmail.com
}

\begin{abstract}
Islamic financial institutions in their operations require legislation. In addition, practitioners of sharia economics also need a fatwa from the National Sharia Council-Indonesian Ulema Council (DSN-MUI) to guarantee the implementation of Sharia principles in sharia financial institutions. Although the fatwa is basically an advice that can be carried out or ignored, but the DSN-MUI Fatwa if it is related to positive law, the position is the same as the doctrine that is as an amplifier in the legal ruling of a qadhi in a case. The DSN-MUI fatwa also has authority and an important role in making legislation binding, and is used as a positive law in enhancing the development of sharia economics in Indonesia. The legal aspects contained in the DSN-MUI fatwa, can be seen from the absorption of the DSN-MUI fatwa in various regulations relating to the operations of Islamic financial institutions, and have been transformed into the form of laws. Thus, the legal strength of the DSN-MUI fatwa becomes binding in the operations of Islamic financial institutions.
\end{abstract}

Keywords: fatwa; National Sharia Council; Islamic financial institution

\begin{abstract}
Abstrak: Lembaga keuangan syariah dalam operasionalnya memerlukan peraturan perundang-undangan. Selain itu, para praktisi ekonomi syariah juga memerlukan fatwa Dewan Syariah Nasional-Majelis Ulama Indonesia (DSN-MUI) untuk menjamin terlaksananya prinsip syariah dalam lembaga keuangan syariah. Walaupun pada dasarnya fatwa merupakan sebuah nasehat yang boleh dijalankan atau diabaikan, namun Fatwa DSN-MUI apabila dikaitkan dalam hukum positif, kedudukannya sama dengan doktrin yaitu sebagai penguat dalam putusan hukum seorang hakim dalam sebuah perkara. Fatwa DSN-MUI juga mempunyai otoritas dan peran penting dalam pembuatan perundang-undangan yang bersifat mengikat, dan dijadikan sebagai hukum positif dalam meningkatkan perkembangan ekonomi syariah di Indonesia. Aspek hukum yang terdapat di dalam fatwa DSN-MUI, tampak dari terserapnya fatwa DSN-MUI di dalam berbagai peraturan terkait operasional lembaga keuangan Syariah, dan telah ditransformasikan ke dalam bentuk undang-undang. Dengan demikian, kekuatan hukum fatwa DSN-MUI menjadi mengikat dalam operasional lembaga keuangan syariah.
\end{abstract}

Kata kunci: fatwa; Dewan Syariah Nasional; lembaga keuangan syariah

\section{Pendahuluan}

Kemajuan dalam bidang ilmu pengetahuan dan teknologi disertai tuntutan pembangunan yang menyentuh seluruh aspek kehidupan, termasuk pada bidang ekonomi. Di samping membawa berbagai kemudahan dan kebahagiaan, menimbulkan sejumlah prilaku dan persoalanpersoalan baru. Banyak persoalan yang beberapa waktu lalu tidak pernah dikenal, bahkan tidak pernah terbayangkan, kini hal itu menjadi kenyataan. ${ }^{1}$

Perdebatan terkait bagaimana eksistensi ekonomi Islam terus menuai perhatian, ada yang berpendapat bahwa ekonomi Islam pada dasar-

${ }^{1}$ Himpunan Fatwa Majelis Ulama Indonesia sejak 1975, (Jakarta: Erlangga, 2011), h. 3. 
nya adalah sama dengan ekonomi konvensional, hanya saja ditambah dengan Islam. Ada pula yang mengatakan bahwa ekonomi Islam adalah ekonomi yang sama sekali tidak berbeda dengan ekonomi lainnya, dengan minus kapitalis dan sosialis, serta penambahan Islam. Pendapat yang lainnya mengatakan bahwa ekonomi Islam lebih banyak mengadopsi dari sistem ekonomi yang sudah ada, dengan mengungkapkan kelemahan sistem lain guna menunjukkan bahwa ekonomi Islam secara substansial adalah yang lebih baik. ${ }^{2}$

Maka, sudah merupakan kewajaran jika setiap timbul persoalan baru, umat berhak mendapatkan jawaban yang tepat dari pandangan ajaran Islam. Fatwa merupakan produk hukum Islam yang sudah ada semenjak masa Nabi saw, kemudian menjadi produk hukum Islam yang berkembang hingga sekarang. Fatwa-fatwa ulama Islam yang terhimpun dalam kitab-kitab fikih dan keputusan-keputusan lembaga fatwa adalah sebagian dari ijtihad yang bersifat kasuistik, karena merupakan respons atau jawaban terhadap pertanyaan yang diajukan oleh peminta fatwa. ${ }^{3}$ Jadi, fatwa merupakan salah satu solusi dalam memecahkan persoalan yang terjadi di zaman modern ini.

Majelis Ulama Indonesia (selanjutnya disingkat MUI) yang merupakan wadah musyawarah para ulama, zu'ama, dan cendikiawan muslim serta menjadi pengayom bagi seluruh muslim Indonesia adalah lembaga paling berkompeten dalam menjawab dan memecahkan setiap masalah sosial keagamaan yang senantiasa timbul dan dihadapi masyarakat. MUI juga telah mendapat kepercayaan dari masyarakat maupun dari pemerintah.

Bidang ekonomi, MUI membentuk lembaga perangkat kerja yaitu Dewan SYariah Nasional (selanjutnya disingkat DSN) yang secara khusus menangani masalah-masalah yang berhubungan

${ }^{2}$ Toha Andiko, "Signifikansi Implementasi Konsep Ekonomi Islam dalam Transaksi Bisnis di Era Modern”, Jurnal Ilmiah Mizani: Wacana Hukum, Ekonomi dan Keagamaan, Vol. 4, No. 1 (2017), h. 9.

${ }^{3}$ Badri Khaeruman, Hukum Islam Dalam Perubahan Sosial, (Bandung: Pustaka Setia, 2010), h. 103 dengan aktivitas Lembaga Keuangan Syariah (LKS) dan ekonomi syariah. Hal ini tertuang pada SK dewan pimpinan MUI No. Kep-754/MUI/ II/1999 tertanggal 10 Februari 1999. ${ }^{4}$ Tugas dan fungsi DSN-MUI adalah mengeluarkan fatwa tentang ekonomi syariah untuk dijadikan pedoman bagi praktisi dan regulator. Saat ini, DSN-MUI telah mengeluarkan fatwa sebanyak 81 fatwa. Namun, DSN-MUI itu sendiri belum diketahui kekuatan hukum fatwanya dalam hukum positif jika dijadikan dasar operasional lembaga keuangan syariah. Walaupun begitu, faktanya tidak sedikit fatwa DSN-MUI yang terserap dalam berbagai peraturan perundangundangan khususnya di bidang ekonomi syariah pada lembaga keuangan syariah.

Penulis ingin mengkaji lebih dalam mengenai aspek hukum yang dilahirkan fatwa DSN-MUI sebagai landasan operasional lembaga keuangan syariah di dalam hukum nasional. Adapun beberapa buku dan artikel yang mempunyai keterkaitan dalam tulisan ini di antaranya pertama, jurnal yang berjudul "Kedudukan Fatwa DSN-MUI Dalam Mendorong Perkembangan Bisnis Perankan Syariah (Perspektif Hukum Perbankan Syariah)", Jurnal ini diterbitkan oleh Rechts Vinding Media Pembinaan Hukum Nasional tahun 2012, ditulis oleh Ahyar Ari Gayo dan Ade Irawan Taufik. ${ }^{5}$ Di dalam jurnal ini mempunyai beberapa pembahasan, di antaranya adalah tentang konsepsi fatwa DSN-MUI, konsepsi perbankan syariah, dan kedudukan fatwa DSN-MUI dalam perspektif hukum perbankan syariah".

Kedua, "Peranan MUI dan Metodologi Istinbat Fatwa dalam Undang-Undang Perbankan Syariah di Indonesia" (The Role of MUI and Methodology of Istinbat Fatwa in Indonesian Banking Law). Jurnal ini ditulis oleh Ahmad Hidayat Buang

\footnotetext{
4 Pedoman Penyelenggaraan Organisais Majelis Ulama Indonesia, (Jakarta: Sekretariat Majelis Ulama Indonesia Pusat, 2011), h. 177.

Ahyar Ari Gayo dan Ade Irawan Taufik, "Kedudukan Fatwa DSN-MUI Dalam Mendorong Perkembangan Bisnis Perankan Syariah (Perspektif Hukum Perbankan Syariah)", Rechts Vinding Media Pembinaan Hukum Nasional, Vol. 1, No. 2, Agustus 2012.
} 
dari Universiti Malaya dan M. Cholil Nafis dari Pusat Studi Timur Tengah, Universitas Indonesia tahun 2012, dan menggunakan Bahasa melayu/ bahasa Malaysia. Pembahasannya di antaranya metodologi fatwa Dewan Syariah Nasional MUI, perundangan perbankan syariah di Indonesia, dan peranan Fatwa DSN-MUI dalam perundangan perbankan syariah. ${ }^{6}$

Ketiga, "Tipologi Fatwa di Era Modern: dari Offline ke Online". Artikel ini ditulis oleh Rusli, membahas tentang tipologi fatwa di era kontemporer. Diasumsikan bahwa perubahan paradigma akan berdampak pada perubahan pengetahuan dan media transmisinya. Hal ini juga berlaku pada fatwa. Karena perubahan paradigma ini, fatwa pun telah mengalami perubahan, baik dari segi isi maupun medianya. Di era globalisasi ini, yang ditandai dengan kemajuan teknologi informasi, fatwa dapat dibagi ke dalam beberapa kategori, seperti fatwa negara, individu, kolektif dan fatwa online. Bentuk-bentuk fatwa ini masing-masing memiliki karakter tersendiri dalam hal ideologi, kepentingan, dan lingkup transmisi. ${ }^{7}$

Artikel ini termasuk penelitian pustaka (library research), bersifat deskriptif kualitatif. Deskriptif adalah menggambarkan sifat sesuatu yang berlangsung pada saat penelitiab dilakukan dan memeriksa sebab-sebab dari suatu gejala tertentu ${ }^{8}$. Kualitatif adalah prosedur yang menghasilkan data deskriptif berupa kata-kata tertulis atau lisan dari orang-orang dan prilaku yang dapat diamati'.

Sumber data artikel ini merupakan sumber data sekunder yakni data yang diperoleh dari dokumen-dokumen resmi, buku-buku yang

${ }^{6}$ Ahmad Hidayat Buang dan M. Cholil Nafis, "Peranan MUI dan Metodologi Istinbat Fatwa dalam Undang-Undang Perbankan Syariah di Indonesia (The Role of MUI and Methodology of Istinbat Fatwa in Indonesian Banking Law)', Jurnal Pengurusan, Vol. 35, 2012.

${ }^{7}$ Rusli, "Tipologi Fatwa di Era Modern: dari Offline ke Online", Palu: Hunafa: Jurnal Studia Islamika, Vol. 8, No. 2, Desember 2011.

${ }^{8}$ Husein Umar, Metode Artikel Untuk Skripsi dan Tesis Bisnis, (Jakarta: PT. Raja Grafindo Persada 2011), h. 22.

9 Nurul Zuriah, Metodologi Artikel Sosial danPendidikan Teori-Aplikasi, (Jakarta:Bumi Aksara ,2009), h. 92. berhubungan dengan obyek artikel, hasil artikel dalam bentuk laporan, tesis, disertasi dan peraturan perundang-undangan. ${ }^{10}$ Sementara sumber tersier didapat dari kamus, ensiklopedi, internet dan lain-lain.

Untuk pengolahan data, data yang terkumpul dipilah dan dipisah, mana yang relevan dengan pembahasan, diambil dan dianalisis sedemikian rupa secara kritis objektif agar dapat ditarik suatu kesimpulan yang dapat dipertanggungjawabkan secara ilmiah. Analisis data menggunakan analisis isi yang lazim dipakai dalam dunia hukum Islam maupun dalam hukum positif di Indonesia.

\section{Konsep Fatwa}

Menurut Kamus Besar Bahasa Indonesia, fatwa adalah jawab (keputusan, pendapat) yang diberikan kepada mufti tentang sesuatu masalah ${ }^{11}$. Fatwa adalah nasihat ulama, petuah orang agung ${ }^{12}$. Al-Fatwa atau Istifta secara etimologi ialah menyelesaikan setiap problem. ${ }^{13}$ Sedangkan secara terminologi ialah menyampaikan hukum-hukum Allah berdasarkan dalil-dalil syariah yang mencakup segala persoalan. ${ }^{14}$ Fatwa merupakan bagian produk hukum Islam yang sudah ada semenjak masa Nabi saw, lalu menjadi produk hukum Islam yang berkembang hingga sekarang. Amir Syarifudin menjelaskan pengertian Ifta' atau fatwa adalah usaha memberikan penjelasan tentang hukum syara'. ${ }^{15}$

Dalam Mu'zam Lughat al-Fuqaha sebagaimana dikutip oleh Badri Kearuman, fatwa didefinisikan sebagai berikut:

${ }^{10}$ Zainudin Aili, Metodologi Artikel Hukum, (Jakarta : Sinar Grafika, 2009), h. 106.

${ }^{11}$ Kamus Besar Bahasa Indonesia, edisi ke 3, cetakan I, (Jakarta, Balai Pustaka 2001), h. 314.

${ }_{12}$ Amran YS Caniago, Kamus Lengkap Bahasa Imdonesia (Dilengkapi dengan singkatan-singkatan) (Bandung, CV Pustaka Setia 1997), h. 190.

${ }^{13}$ Khairul Uman dan A. Ahyar Aminudin, Ushul Fiqh II, (Bandung: Pustaka Setia, 1998), h. 173.

${ }^{14}$ Khairul Uman dan A. Ahyar Aminudin, Ushul Figh II, h. 175 .

${ }^{15}$ Amir Syarifudin, Ushul Fiqh Jilid 2, (Jakarta: Kencana, 2009), h. 45. 


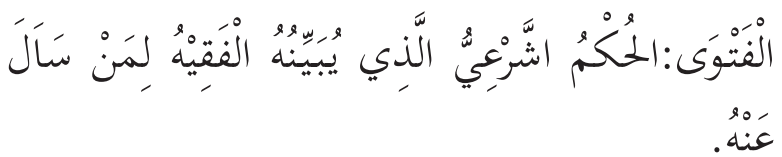

"Fatwa adalah hukum syar'i (keagamaan) yang dijelaskan oleh seorang faqih untuk orang yang bertanya kepadanya".

Dalam ilmu Ushul al-Fiqh, fatwa berarti pendapat yang dikemukakan seorang mujtahid atau faqih sebagai jawaban yang diajukan peminta fatwa dalam suatu kasus yang sifatnya tidak mengikat. Pihak yang meminta fatwa tersebut bisa pribadi, lembaga, maupun kelompok masyarakat. Fatwa yang dikemukakan mujtahid atau faqih tersebut tidak mesti diikuti oleh orang yang meminta fatwa, dan karenanya fatwa tersebut tidak mempunyai daya ikat. Pihak yang memberi fatwa dalam istilah Fikih dan Ushul al-Fiqh disebut al-mufti, sedangkan pihak yang meminta fatwa disebut al-mustafti. ${ }^{16}$

Di kalangan ulama mazhab, fatwa diberikan pengertian yang beragam, namun tetap mempunyai kesamaan sebagai jawaban terhadap suatu persoalan yang ditanyakan. Menurut ulama mazhab Hanafi, iftâ' adalah menjelaskan hukum terhadap suatu permasalahan (bayân hukm al-kaq'ajah). Dalam pandangan ulama mazhab Mâlikî, iftâ' adalah menginformasikan tentang suatu hukum syariat dengan cara yang tidak mengikat (al-ikbbâr bi al-bukm al-syarî̀ 'ajâ ghair wajh al-ilzâm) ${ }^{17}$.

Menurut Quraish Shihab sebagaimana dikutip oleh Badri Kaeruman, fatwa berasal dari bahasa arab al-ifta, al-fatwa yang secara sederhana dimengerti sebagai "pemberian keputusan". Fatwa bukanlah keputusan hukum yang dibuat dengan mudah dan sekehendak hati, seperti membuat-buat hukum tanpa dasar (al-tahakkum). Fatwa senantiasa terikat dengan siapa yang berwenang memberi fatwa (Ijazah alifta), kode etik fatwa (adab al-ifta), dan metode pembuatan fatwa (al-istimbath). ${ }^{18}$ Sementara itu menurut al-Syatibi, fatwa dalam arti al-ifta

\footnotetext{
${ }^{16}$ Badri Kaerumam, Hukum Islam..., h. 105.

${ }^{17}$ Rusli, Tipologi Fatwa..., h. 266.

${ }^{18}$ Badri Kaerumam, Hukum Islam..., h. 106.
}

berarti keterangan-keterangan tentang hukum syara' yang tidak mengikat untuk diikuti. ${ }^{19}$

Pemaparan di atas dapat di pahami bahwa fatwa merupakan salah satu produk hukum Islam yang mempunyai fungsi menjawab sebuah pertanyaan yang terjadi dan belum pernah ada di zaman Rasulullah saw.

\section{Tinjauan Terhadap Dewan Syariah Nasional- Majelis Ulama Indonesia (DSN-MUI) Sejarah Lahirnya DSN-MUI}

Dengan semakin berkembangnya lembagalembaga keuangan syariah di tanah air akhirakhir ini, dan adanya Dewan Pengawas Syariah pada setiap lembaga keuangan syariah, dipandang perlu didirikan Dewan Syariah Nasional (DSN) yang akan menampung berbagai masalah/kasus yang memerlukan fatwa, agar diperoleh kesamaan dalam penanganannya pada masing-masing Dewan Pengawas Syariah yang ada di lembaga keuangan syariah. ${ }^{20}$

Rencana pembentukan DSN mulai dibicarakan tahun 1990 ketika acara lokakarya dan pertemuan yang membahas tentang bunga bank dan pengembangan ekonomi rakyat, dan merekomendasikan agar pemerintah memfasilitasi pendirian bank berdasarkan prinsip syariah. Pada tahun 1997, MUI mengadakan lokakarya ulama tentang Reksadana Syariah yang salah satu rekomendasinya adalah pembentukan DSN. ${ }^{21}$ Pada pertemuan tanggal 14 Oktober 1997, telah disepakati pembentukan DSN. Usulan ini ditindaklanjuti sehingga tersusunlah DSN secara resmi tahun $1998 .^{22}$

DSN adalah lembaga yang dibentuk oleh MUI yang secara struktural berada di bawah

${ }^{19}$ Ahyar Ari Gayo dan Ade Irawan Taufik, "Kedudukan Fatwa Dewan Syariah Nasional Majelis Ulama Indonesia dalam Mendorong Perkembangan Bisnis Perbankan syariah (perspektif Hukum Perbankan Syariah", Jurnal Rechtsvinding Media Pembinaan Hukum Nasional, Vol. 1, Nomor 2, Agustus 2012, h. 261.

${ }^{20}$ Ahyar A. Gayo, Artikel Hukum..., h. 43.

${ }^{21}$ Muhammad Syafi'i Antonio, Bank Syariah: Dari Teori ke Praktik, (Jakarta: Gema Insani, 2001), h. 32.

${ }^{22}$ M. Cholil Nafis, Teori Hukum Ekonomi Syariah, (Jakarta: UI Pers, 2011), h. 82. 
MUI. Tugas DSN adalah menjalankan tugas MUI dalam menangani masalah-masalah yang berhubungan dengan ekonomi syariah, baik yang berhubungan dengan aktivitas lembaga keuangan syariah ataupun yang lainnya. Pada prinsipnya, pembentukan DSN dimaksudkan oleh MUI sebagai usaha untuk efisiensi dan koordinasi para ulama dalam menanggapi isuisu yang berhubungan dengan masalah ekonomi dan keuangan. Disamping itu, DSN diharapkan dapat berperan sebagai pengawas, pengarah dan pendorong penerapan nilai-nilai dan prinsipprinsip ajaran Islam dalam kehidupan ekonomi. Oleh sebab itu, DSN berperan secara proaktif dalam menanggapi perkembangan masyarakat Indonesia di bidang ekonomi dan keuangan. ${ }^{23}$

Otoritas tertinggi syariah di Indonesia berada pada Dewan Syariah Nasional-Majelis Ulama Indonesia (DSN-MUI), yang merupakan lembaga independen dalam mengeluarkan fatwa yang berhubungan dengan semua masalah syariah, baik masalah ibadah maupun muamalah, termasuk masalah ekonomi, keuangan dan perbankan.

\section{Peran dan Tugas DSN-MUI}

Salah satu tugas utama lembaga DSN adalah menggali, mengkaji dan merumuskan nilai dan prinsip-prinsip hukum Islam (syariah) dalam bentuk fatwa untuk dijadikan panduan dalam kegiatan dan urusan ekonomi pada umumnya dan khususnya terhadap urusan dan kegiatan transaksi lembaga keuangan syariah, yaitu untuk menjalankan operasional lembaga keuangan syariah dan mengawasi pelaksanaan dan implementasi fatwa. ${ }^{24}$ Untuk melaksanakan tugas utama tersebut, DSN memiliki otoritas untuk: ${ }^{25}$

1. Mengeluarkan fatwa yang mengikat Dewan Pengawas Syariah di masing-masing Lembaga Keuangan Syariah dan menjadi dasar tindakan hukum pihak terkait.

\footnotetext{
${ }^{23}$ M. Cholil Nafis, Teori Hukum..., h. 182.

${ }^{24}$ Ahyar A. Gayo, Artikel Hukum..., h. 45.

${ }^{25}$ M. Cholil Nafis, Teori Hukum., hlm. 89. Lihat juga Ahyar Ari Gayo dan Ade Irawan Taufik, Kedudukan Fatwa..., h. 262.
}

2. Mengeluarkan fatwa yang menjadi landasan bagi ketentuan/peraturan yang dikeluarkan oleh institusi yang berhak, seperti Kementerian Keuangan dan Bank Indonesia.

3. Memberikan dukungan dan/atau mencabut dan menyokong nama-nama yang akan duduk sebagai Dewan Pengawas Syariah pada suatu Lembaga Keuangan Syariah.

4. Mengundang para ahli untuk menjelaskan suatu masalah yang diperlukan dalam pembahasan ekonomi syariah, termasuk otoritas moneter/lembaga keuangan dalam maupun luar negeri.

5. Memberikan rekomendasi kepada Lembaga keuangan Syariah untuk menghentikan penyimpangan dari fatwa yang telah dikeluarkan oleh Dewan Syariah Nasional.

6. Mengusulkan kepada institusi yang berhak untuk mengambil tindakan apabila perintah tidak didengar.

Dari pemaparan di atas, dapat dipahami bahwa peran dan tugas DSN-MUI sangat penting terutama dalam bidang pengawasan lembaga keuangan syariah, guna menjaga ketertiban dalam operasionalnya. Apabila suatu lembaga keuangan syariah tidak patuh dengan aturan terutama pada aturan syariah, maka DSNMUI bisa mengajukan usulan kepada institusi berwenang untuk diberikan sanksi.

\section{Tinjauan Mengenai Lembaga Keuangan Syariah}

Lembaga keuangan syariah, menurut Ahmad Ifham Sholihin adalah lembaga keuangan yang mengeluarkan produk keuangan syariah dan mendapat izin operasional sebagai lembaga keuangan syariah ${ }^{26}$. Jadi menurut penulis, lembaga keuangan syariah harus mengeluarkan produk berdasarkan ketentuan syariah, apabila tidak mendapatkan izin operasional dari pihak terkait

26 Ahmad Ifham Sholihin, Pedoman Umum Lembaga Keuangan Syariah, (Jakarta: Gramedia Pustaka Utama, 2010), h. 51. Lihat juga pada Keputusan Dewan Syariah Nasional Majelis Ulama Indonesia Nomor 01 Tahun 2009 tentang Pedoman Dasar Dewan Syaria Nasional-Majelis Ulama Indonesia (PD DSN-MUI) pada bagian II. 
misalnya pada DPS, maka lembaga keuangan syariah tidak boleh mengeluarkan produk maupun operasionalnnya.

Lembaga keuangan syariah mempunyai berbagai bentuk, yaitu: Bank Syariah, Bank Pembiayaan Rakyat Syariah (BPRS), Asuransi Syariah (Takaful), Perusahaan Pembiayaan Syariah, Pasar Modal Syariah, Pegadaian Syariah, Dana Pensiun Syariah, Baitul Mal wat Tamwil (BMT), Pasar Modal Syariah, Lembaga Amil Zakat dan Lembaga Wakaf. ${ }^{27}$ Dalam buku lembaga keuangan syariah karangan M. Nur Rianti Al-Arif, di dalam kata pengantar yang ditulis oleh Juhaya S. Pradja, ia mengemukakan bahwa lembaga keuangan syariah ada yang merupakan lembaga bank dan lembaga non bank..$^{28}$

\section{a. Lembaga Keuangan Bank (LKB)}

Salah satu institusi yang memiliki peranan penting dalam dunia bisnis adalah lembaga keuangan perbankan. Menurut Undang-undang Perbankan nomor 10 Tahun 1998 tentang perubahan atas Undang-undang nomor 7 Tahun 1992, yang dimaksud bank adalah badan usaha yang menghimpun dana dari masyarakat dalam bentuk simpanan dan menyalurkannya kepada masyarakat dalam bentuk kredit dan atau bentukbentuk lainnya dalam rangka meningkatkan taraf hidup rakyat. ${ }^{29}$ Institusi perbankan merupakan subsistem dari keberadaan lembaga keuangan (financial institution). Menurut hukum perbankan yang berlaku saat ini, Indonesia adalah negara yang menganut konsep perbankan nasional dengan sistem ganda (dual banking system). Artinya bahwa selain ada perbankan konvensional yang beroperasi berdasarkan sistem "bunga", juga ada perbankan lain yang menjalankan kegiatan usahanya berdasarkan prinsip-prinsip syariah. ${ }^{30}$

27 Imam Mustofa, Ijtihad Kontemporer Menuju Figh Kontekstual, (Jakarta: Rajawali Pers, 2013), h.29., lebih lanjut baca M. Nur Rianto Al Arif, Lembaga Keuangan Syariah Suatu Kajian Teoritis Praktis, (Bandung: Pustaka Setia, 2012), h. 79, baca juga Heri Sudarsono, Bank dan Lembaga Keuangan Syariah: Deskripsi dan Ilustrasi, (Yogyakarta: Ekonisia, cetakan kedua, 2004).

${ }^{28}$ M. Nur Rianto al Arif, Lembaga Keuangan Syariah, h. 3.

${ }^{29}$ Lihat pada pasal 1 UU no. 10 Tahun 1998.

30 Prinsip syariah adalah aturan perjanjian berdasarkan

\section{b. Lembaga Keuangan Bukan Bank (LKBB)}

Adalah semua badan usaha yang melakukan kegiatan di bidang keuangan, baik secara langsung atau tidak langsung menghimpun dana, terutama dengan jalan mengeluarkan kertas berharga dan menyalurkan kepada masyarakat terutama guna membiayai investasi perusahaan. Dalam dunia bisnis, lembaga keuangan bukan bank jumlahnya sangat beragam. Bahkan bisa dikatakan bahwa semua lembaga keuangan yang bukan bagian dari kegiatan perbankan adalah termasuk pada kategori ini. ${ }^{31}$

Jadi, dapat dipahami bahwa baik lembaga keuangan bank (LKB) maupun lembaga keuangan bukan bank (LKBB) apabila mendirikan sebuah lembaga keuangan syariah, haruslah tetap mentaati ketetapan syariah meskipun notabenenya berasal dari lembaga keuangan yang konvensional.

\section{Eksistensi Fatwa Dalam Hukum Islam}

Fatwa menempati kedudukan penting dalam hukum Islam, karena fatwa merupakan pendapat yang dikemukakan oleh ahli hukum Islam (fuqaha) tentang kedudukan hukum suatu masalah baru yang muncul di kalangan masyarakat. Ketika muncul suatu masalah baru yang belum ada ketentuan hukumnya secara eksplisit (tegas), baik dalam Alquran, Sunah dan ijma maupun pendapat-pendapat fuqaha terdahulu, maka fatwa merupakan salah satu institusi normatif yang berkompeten menjawab atau menetapkan kedudukan hukum masalah tersebut. Karena kedudukannya yang dianggap dapat menetapkan hukum atas suatu kasus atau masalah tertentu, maka para sarjana Barat ahli hukum Islam mengkategorikan fatwa sebagai jurisprudensi Islam. $^{32}$ Sehubungan

hukum Islam antara bank dan pihak lain untuk penyimpanan dana dan atau pembayaran kegiatan usaha, atau kegiatan lain yang dinyatakan sesuai dengan syariah. lihat M. Nur Rianto al Arif, Lembaga Keuangan Syariah, h. 3.

${ }^{31}$ Burhanuddin S., Hukum Bisnis, h. 115.

${ }^{32}$ M. Erfan Riadi, "Kedudukan Fatwa Ditinjau dari Hukum Islam dan Hukum Positif (Analisis Yuridis Normatif)", Jurnal Ulumuddin, Volume VI, Tahun IV, Januari-Juni 2010, h. 472 
dengan hal di atas, maka fatwa bisa diartikan sebagai penjelasan hukum syariat atas persoalan tertentu, sehingga kaedah pengambilan fatwa tidak ubahnya dengan kaedah menggali hukumhukum syariat dari dalil-dalil syariat (ijtihâd).

Kedudukan fatwa dalam hukum Islam dapat dikaji dari pengertian fatwa, sehingga bila berbicara mengenai fatwa, maka tidak akan lepas dari aspek siapa atau organisasi apa yang memuat fatwa tersebut. ${ }^{33}$ Oleh sebab itu, dapat dipahami bahwa berbicara tentang fatwa, maka tidak terlepas pembicaraan tersebut terhadap konsep ijtihad. Selain itu, kedudukan fatwa sangatlah penting dalam hukum Islam khususnya dalam mengakomodir masalah hukum yang ada di masyarakat dengan lahirnya ekonomi syariah.

\section{Kedudukan Fatwa Ditinjau dari Hukum Positif Indonesia}

Dengan model hukum tata negara di zaman modern ini, fungsi fatwa dalam suatu negara dapat dikelompokkan menjadi tiga fungsi. ${ }^{34}$ Pertama, negara yang menempatkan syariat Islam sebagai dasar dan undang-undang negara yang diterapkan secara utuh dan sempurna, sehingga fatwa menjadi keputusan hukum yang mengikat. Kedua, negara yang berdasarkan hukum sekuler, maka fatwa tidak berperan dan tidak berfungsi apa pun dalam kehidupan bernegara. Ketiga, negara yang menggabungkan antara hukum sekuler dengan hukum Islam, maka fatwa berfungsi hanya dalam ranah hukum Islam.

Melihat kenyataan yang ada di Indonesia, Indonesia dapat dikategorikan sebagai negara yang menggunakan pola ketiga. Sehingga kajian fatwa di Indonesia terasa sangat menarik karena mayoritas penduduk Indonesia beragama Islam penganut mazhab Sunni, namun negara berdasarkan Pancasila ${ }^{35}$.

${ }^{33}$ Ahyar A. Gayo, Artikel Hukum tentang Kedudukan Fatwa MUI dalam Upaya Mendorong Pelaksanaan Ekonomi Syariah, (BPHN Puslitbang, 2011), h. 19.

${ }^{34}$ Ahyar Ari Gayo dan Ade Irawan Taufik, Kedudukan Fatwa DSN-MUI, h. 265.

${ }^{35}$ Murtadho Ridwan, Analisis Fatwa MUI Tentang Asuransi
Berdasarkan sumber hukum yang berlaku dalam sistem hukum nasional, yakni dalam sistem hukum nasional secara formal terdapat lima sumber hukum, adapun sumber hukum tersebut sebagai berikuti: undang-undang, kebiasaan, putusan hakim (yurisprudensi), traktat, serta doktrin (pendapat pakar pakar/ahli hukum). ${ }^{36}$ Dalam kelima sumber hukum tata negara tersebut, tercakup pula pengertian-pengertian yang berkenaan dengan: (i) nilai-nilai dan norma hukum yang hidup sebagai konstitusi yang tidak tertulis; (ii) kebiasaan-kebiasaan yang bersifat normative tertentu yang diakui baik dalam lalu lintas hukum yang lazim; dan (iii) doktrin-doktrin ilmu pengetahuan hukum yang telah diakui sebagai ius comminis opinion doctorum di kalangan para ahli yang mempunyai otoritas yang diakui umum. ${ }^{37}$ Dalam setiap sistem hukum, ketiga hal ini bisa juga dianggap sebagai sumber hukum yang dapat dijadikan referensi atau rujukan dalam membuat keputusan hakim. ${ }^{38}$

Kemudian untuk dapat mengetahui tata urutan peraturan perundang-undangan yang berlaku di Indonesia, maka bisa dilihat dalam undangundang nomor 12 tahun 2011 tentang Peraturan Perundang-Undangan, tepatnya dalam pasal 7 sebagai berikut: Undang-Undang Dasar 1945, Ketetapan MPR, undang-undang/peraturan pemerintah pengganti undang-undang, peraturan pemerintah, peraturan presiden, peraturan daerah provinsi, peraturan daerah kabupaten/ kota. ${ }^{39}$

Sumber hukum positif dalam sistem hukum nasional di atas dan dalam tata urutan peraturan

Syariah Dan Penyerapannya Ke Dalam Peraturan PerundangUndangan dalam buku yang bertajuk Fatwa Majelis Ulama Indonesia (MUI) Dalam Perspektif Hukum Dan PerundangUndangan, (Jakarta: Puslitbang Lektur dan Khazanah Keagamaan Badan Litbang Dan Diklat Kementerian Agama RI, 2012), h. 257.

${ }^{36}$ M. Erfan Riadi, Kedudukan Fatwa, h. 474. Bandingkan dengan Chainur Arrasjid, Dasar-Dasar Ilmu Hukum, (Jakarta: Sinar Grafika, 2001), h. 50.

37 Jimly Asshiddiqie, Pengantar Ilmu Hukum Tata Negara, (Jakarta: Rajawali Pers, 2010), h. 128.

${ }^{38}$ Jimly Asshiddiqie, Pengantar..., h. 128.

39 Ahyar Ari Gayo dan Ade Irawan Taufik, Kedudukan Fatwa...,h. 265. 
perundang-undangan, sebagaimana telah disebutkan dalam Undang-Undang nomor 12 Tahun 2011 tentang Peraturan PerundangUndangan, tidak menyebutkan fatwa sebagai bagian dari dasar hukum di negara ini, sehingga fatwa DSN-MUI tidak dapat dijadikan sebagai landasan hukum ${ }^{40}$.

M. Erfan Riadi mengemukakan bahwa fatwa hanya sebagai suatu pendapat atau nasehat yang disampaikan oleh para ahli hukum Islam yang tergabung dalam suatu wadah organisasi, seperti Muhammadiyah, NU, Persis, dan lembaga lainnya. ${ }^{41}$ Sehingga fatwa dapat dikorelasikan dengan sumber hukum formal dalam sistem hukum nasional, yakni kedudukan fatwa sama dengan doktrin yang merupakan pendapat pakar atau pendapat para ahli di bidang hukum positif.

Dalam praktik, doktrin ${ }^{42}$ (pendapat ahli hukum) banyak mempengaruhi pelaksanaan administrasi Negara, demikian juga dalam proses pengadilan. Seorang hakim diperkenankan menggunakan pendapat ahli untuk dijadikan sebagai pertimbangan hakim dalam memutus sebuah perkara, kemudian bagi seorang pengacara/ pembela yang sedang melakukan pembelaannya pada suatu perkara perdata, seringkali mengutip pendapat-pendapat ahli sebagai penguat pembelaannya.

Pengadilan Agama memakai fatwa sebagai landasan hukum, yakni fatwa yang disepakati oleh Mahkamah Agung bersama Pengadilan Agama. Kemudian sebagai contoh bahwa fatwa juga telah digunakan oleh hakim sebagai pertimbangan dalam memutus perkara perdata yakni pada undang-undang nomor 50 tahun 2009 tentang Pengadilan Agama disebutkan bahwa Pengadilan Agama berwenang untuk menyelesaikan sengketa ekonomi syariah, maka dari itu produk fatwa MUI dijadikan sebagai dasar untuk memutus sebelum ada undang-undang

\footnotetext{
${ }^{40}$ M. Erfan Riadi, Kedudukan Fatwa., h. 474.

${ }^{41}$ M. Erfan Riadi, Kedudukan Fatwa., h. 474.

${ }^{42}$ Doktrin asal kata dari doctrine yang berarti ajaran. Lihat Simonangkir dkk, Kamus Hukum, (Jakarta: Sinar Grafika, 2009), h. 39.
}

tentang ekonomi syariah, misalnya fatwa MUI nomor 21 tahun 2001 tentang pedoman umum asuransi syariah ${ }^{43}$, fatwa MUI no 3 tahun 2003 tentang zakat penghasilan, dan fatwa-fatwa lain tentang ekonomi yang berbasis syariah.

Jadi, apabila fatwa DSN-MUI dikaitkan dalam hukum positif, kedudukan fatwa sama dengan doktrin yaitu sebagai penguat dalam pemutusan seorang hakim dalam sebuah perkara, namun fatwa pada hakikatnya hanyalah sebuah petuah atau nasihat dari seorang alim ulama yang bersifat tidak mengikat.

\section{Legalitas Fatwa DSN-MUI}

Dalam catatan sejarah, sejak berdirinya DSN-MUI sampai dengan sekarang, telah banyak fatwa dan nasihat DSN-MUI sebagai produk pemikiran hukum Islam yang terserap dalam berbagai peraturan perundang-undangan, khususnya di bidang ekonomi syariah. Indikator yang mendukung kecenderungan tersebut dapat dilihat dari lahirnya beberapa peraturan perundang-undangan, antara lain:

1) Undang-Undang Nomor 10 Tahun 1998 tentang perubahan atas undang-undang No. 7 tahun 1992 tentang perbankan;

Undang-undang nomor 1 Tahun 1998 merupakan suatu titik awal pengakuan perbankan syariah secara eksplisit dalam peraturan perundang-undangan. Di dalam undang-undang nomor 10 Tahun 1998 disebutkan secara tegas kata "Prinsip Syariah" ${ }^{4}$

\footnotetext{
${ }^{43}$ Asuransi syariah adalah usaha saling melindungi dan saling menolong di antara sejumlah orang/ pihak melalui investasi dalam bentuk asset dan atau tabarru' yang memberikan pola pengembalian untuk menghadapi risiko tertentu melalui akad yang sesuai denga.Syariah. Lihat Muhammad Syakir Sula, Asuransi Syariah, (Jakarta: Gema Insani Press, 2004), h. 42.

44 Prinsip Syariah adalah aturan perjanjian berdasarkan hukum Islam antara bank dan pihak lain untuk penyimpanan dana dan atau pembiayaan kegiatan usaha, atau kegiatan lainnya yang dinyatakan sesuai dengan syariah, antara lain pembiayaan berdasarkan prinsip bagi hasil (mudharabah), pembiayaan berdasarkan prinsip penyertaan modal (musharakah), prinsip jual beli barang dengan memperoleh keuntungan (murabahah), atau pembiayaan barang modal berdasarkan prinsip sewa murni tanpa pilihan (ijarah), atau dengan adanya pilihan pemindahan kepemilikan atas barang yang disewa dari pihak bank oleh pihak
} 
di dalam Pasal 1 angka $(3,4,12,13,18)$, pasal 6 huruf (M), pasal 7 huruf (c), pasal 8 (1 dan $2)$, pasal 11 ayat $(1$ dan 3$) ;{ }^{45}$

2) Undang-Undang nomor 21 Tahun 2008 tentang Perbankan Syariah;

Dalam pasal 26 Undang-undang Nomor 21 Tahun 2008 dinyatakan: ${ }^{46}$

a) Kegiatan usaha sebagaimana dimaksud dalam pasal 19, pasal 20, dan pasal 21 dan atau produk dan jasa syariah, wajib tunduk kepada Prinsip Syariah.

b) Prinsip Syariah sebagaimana dimaksud pada ayat 1 difatwakan oleh Majelis Ulama Indonesia.

c) Fatwa sebagaimana dimaksud pada ayat 2 dituangkan dalam Peraturan Bank Indonesia.

d) Dalam rangka penyusunan Peraturan Bank Indonesia sebagaimana dimaksud pada ayat 3, Bank Indonesia membentuk komite perbankan syariah.

Ketentuan lebih lanjut mengenai tata cara pembentukan, keanggotaan, dan tugas komite perbankan syariah sebagaimana dimaksud pada ayat 4 diatur dengan Peraturan Bank Indonesia.

3) KMA/032/SK/IV/2006 tentang Pemberlakuan Buku II Pedoman pelaksanaan Tugas dan Adminitrasi Pengadilan;

Pada KMA tersebut dinyatakan dalam bagian II Teknis Peradilan dalam sub bab kedudukan dan kewenangan Pengadilan Agama/ Mahkamah Syar'iyah, terdapat pembahasan hukum materil yang digunakan Pengadilan Agama/ Mahkama Syar'iyah dan pada bagian ke 19 tercantum Fatwa DSN-MUI sebagai hukum materil yang digunakan oleh Pengadilan agama/ Mahkamah Syar'iyah ${ }^{47}$.

lain (ijarah wa iqtina). Lihat UU Nomor 10 Tahun 1998 Pasal 1 Angka (13).

45 Undang-Undang Nomor 10 Tahun 1998 tentang Perbankan

46 Undang-undang Nomor 21 Tahun 2008 Tentang Perbankan Syariah Pasal 26.

$\left.{ }^{47} 1\right)$. Alquran dan Hadis; 2). Undang-undang Nomor 22 Tahun 1946 jo. Undang-undang nomor 32 Tahun 1954 tentang
4) Peraturan Mahkamah Agung Nomor 02 Tahun 2008 Tentang Kompilasi Hukum Ekonomi Syariah (KHES);

Fatwa DSN-MUI banyak terserap dalam KHES yang merupakan salah satu hukum materil dalam Pengadilan Agama ${ }^{48}$, serapan DSN-MUI di antaranya adalah:

a) Fatwa jual beli salam ${ }^{49}$ yang terserap dalam buku II tentang akad BAB $\mathrm{V}$ tentang jenis-jenis Jual Beli Bagian Ketiga tentang jual beli dengan Pembayaran Tunai, tetapi penyerahan kemudian (Bai' salam) Pada Pasal 100 sampai Pasal 103. ${ }^{50}$

b) Fatwa Bai' Al-Istishna ${ }^{51}$ yang terserap dalam Buku II Tentang Akad BAB V tentang Akibat Bai', bagian ketiga tentang bai' al-istishna yaitu dalam pasal 104

nikah, talak, cerai dan rujuk (NTCR); 3).Undang-undang nomor 1 tahun 1974 tantang perkawinan; 4).PP No. 9 tahun 1975 tetang Pelaksanaan Undang-undang nomor 1 tahun 1974; 5).UU no. 7 Tahun 1992 tentang Perbankan sebagaimana telah diubah dengan UU no. 10 Tahun 1998; 6).UU no. 23 Tahun 1999 Tentang Bank Indonesia; 7). UU no. 38 Tahun 1999 Tentang Pengelolaan Zakat.; 8). UU no. 41 Tahun 2004 Tentang Wakaf.; 9). UU no. 19 tahun 2008 Tentang Surat Berharga Syariah Negara; 10).UU no. 21 Tahun 2008 tantang Perbankan Syariah.; 11). UU no. 23 Tahun 2002 Tentang Perlindungan Anak.; 12). UU no. 23 tahun 2004 Tentang penghapusan kekerasan dalam rumah tangga.; 13). PP no. 28 Tahun 1997 tentang perwakafan tanak milik.; 14). Kompilasi Hukum Islam (KHI).; 15). PERMA no. 2 Tahun 2008 Tentang KHES.; 16). Peraturan Bank Indonesia yang berkaitan dengan ekonomi syariah.; 17). Yurisprudensi.; 18). Qannun aceh.; 19). Fatwa Dewan Syariah Nasional Majelis Umala Indonesia; 20).Akad ekonomi syariah. Lihat pada Mahkamah Agung RI, Pedoman Pelaksanaan Tugas dan Adminitrasi Peradilan Agama Buku II, (Jakarta: Direktorat Jendral Badan Peradilan Agama), h. 57.

${ }^{48}$ Juhaya S. Pradja, Ekonomi Syariah, (Bandung: CV Pustaka Setia, 2012), h. 207.

${ }^{49}$ DSN-MUI Nomor 05/DSN MUI/ IV/ 2000 tentang jual beli salam, lihat http://www.dsnmui.or.id/index.php?mact=News ,cntnt01, detail,0\&cntnt01 articleid $=101 \& \mathrm{cntnt} 01$ origid $=66 \& \mathrm{cn}$ tnt 01 detailtemplate $=$ Fatwa $\&$ cntnt 01 returnid $=59$, diunduh pada 6 Agustus 2015. Jual beli salam adalah jual beli melalui pesanan, yakni jual beli dengan cara menyerahkan uang muka terlebih dahulu kemudian barang diantar di akhir. Lihat Rachmat Syafe'i, Fiqh Muamalah, (Bandung: Pustaka Setia, 2001), h. 101.

${ }^{50}$ Pusat Pengkajian Hukum Islam dan Masyarakat Madani (PPHIMM), Kompilasi Hukum Ekonomi Syariah, (Jakarta: Kencana, 2009), h. 42

${ }^{51}$ bai' al-istishna adalah Jual beli barang atau jasa dalam bentuk pesanan dengan kriteria dan persyaratan tertentu yang disepakati antara pihak pemesan dan pihak penjual, Ibid, h. 16. Lihat juga pada Ghufron A. Mas'adi, Fiqh Muamalah Kontekstual, (Jakarta: PT Raja Grafindo Persada, 2002), h. 143. 
sampai $108^{52}$, pasal tersebut susbtansinya diambil dari fatwa DSN-MUI No: 06/ DSN-MUI/IV/2000 tentang jual beli istishna' yang memutuskan ketetapan hukum di antaranya; Ketentuan tentang Pembayaran, Ketentuan tentang barang, dan Ketentuan lainnya. ${ }^{53}$

c) Fatwa murabahah terserap dalam buku II tentang akad, bab $\mathrm{V}$ bagian keenam tantang bai' Murabahah Pasal 116-124.

Berikut adalah tabel yang menunjukkan kaitan antara fatwa DSN-MUI dengan KHES selain yang sudah dijelaskan.

\begin{tabular}{c|c|c|c}
\hline $\begin{array}{c}\text { Fatwa DSN- } \\
\text { MUI }\end{array}$ & $\begin{array}{c}\text { Materi } \\
\text { fatwa }\end{array}$ & $\begin{array}{c}\text { Penyerapan } \\
\text { KHES }\end{array}$ & Keterangan \\
\hline No. 8/ 2000 & $\begin{array}{c}\text { Pembiayaan } \\
\text { Musyarakah }\end{array}$ & $\begin{array}{c}\text { BAB VII } \\
\text { syirkah }\end{array}$ & Pasal 178-186 \\
\hline No. 9/ 2000 & $\begin{array}{c}\text { Pembiayaan } \\
\text { ijarah }\end{array}$ & BAB XI Ijarah & Pasal 295-361 \\
\hline No. 10/ 2000 & Wakalah & $\begin{array}{c}\text { BAB XVII } \\
\text { Wakalah }\end{array}$ & Pasal 452-520 \\
\hline No. 11/ 2000 & Kafalah & $\begin{array}{c}\text { BAB XII } \\
\text { Kafalah }\end{array}$ & Pasal 335-361 \\
\hline No. 12/ 2000 & Hawalah & $\begin{array}{c}\text { BAB XIII } \\
\text { Hawalah }\end{array}$ & Pasal 362-372 \\
\hline
\end{tabular}

Di Indonesia, fatwa DSN-MUI mempunyai otoritas dan peran penting dalam pembuatan perundang-undangan yang bersifat mengikat dan dijadikan sebagai hukum positif dalam rangka meningkatkan perkembangan ekonomi syariah di Indonesia.

\section{Penutup}

Berdasarkan uraian-uraian yang telah dijelaskan pada bab-bab sebelumnya, maka dapat ditarik kesimpulan bahwa kedudukan fatwa DSN-MUI sangatlah penting dalam pengembangan hukum Islam. Khususnya dalam mengakomodir masalah hukum yang ada di

\footnotetext{
${ }^{52}$ Pusat Pengkajian Hukum Islam dan Masyarakat Madani (PPHIMM), Kompilasi Hukum Ekonomi Syariah, h. 43.

53 Juhaya S. Pradja, Ekonomi Syariah, h. 211.
}

masyarakat dengan lahirnya ekonomi syariah. Selain itu, fatwa DSN-MUI apabila dikaitkan dalam hukum positif, kedudukan fatwa sama dengan doktrin yaitu sebagai penguat dalam putusan seorang hakim pada sebuah perkara. Fatwa DSN-MUI juga mempunyai otoritas dan peran penting dalam pembuatan perundangundangan yang bersifat mengikat, dan dijadikan sebagai hukum positif dalam rangka meningkatkan perkembangan ekonomi syariah di Indonesia. Aspek hukum yang terdapat di dalam fatwa DSN-MUI dalam operasional adalah terserapnya fatwa DSN-MUI di dalam berbagai peraturan perundang-undangan terkait operasional lembaga keuangan syariah. Hal ini dapat terlihat dari fatwa yang telah ditransformasikan ke dalam bentuk undangundang. Kekuatan hukum fatwa DSN-MUI adalah mengikat dalam operasional lembaga keuangan syariah. Hal tersebut bisa terlihat pada KMA/032/SK/IV/2006 tentang Pemberlakuan Buku II Pedoman pelaksanaan Tugas dan Administrasi Pengadilan. Fatwa DSN-MUI menjadi salah satu hukum materil dalam penyelesaian perkara, khususnya di Peradilan Agama/ Mahkamah Syar'iyah.

\section{Pustaka Acuan}

Ahyar, A. Gayo. Artikel Hukum tentang Kedudukan Fatwa MUI dalam Upaya Mendorong Pelaksanaan Ekonomi Syariah, BPHN Puslitbang, 2011.

Al Arif, M. Nur Rianto. Lembaga Keuangan Syariah Suatu Kajian Teoritis Praktis, Bandung: Pustaka Setia, 2012.

Ali, Zainudin. Metodologi Artikel Hukum, Jakarta: Sinar Grafika, 2009.

Andiko, Toha, "Signifikansi Implementasi Konsep Ekonomi Islam dalam Transaksi Bisnis di Era Modern”, Jurnal Ilmiah Mizani: Wacana Hukum, Ekonomi dan Keagamaan, Vol. 4, No. 1, 2017.

Antonio, Muhammad Syafi'i. Bank Syariah: Dari Teori ke Praktik, Jakarta: Gema Insani, 2001. 
Arrasjid, Chainur. Dasar-Dasar Ilmu Hukum, Jakarta: Sinar Grafika, 2001.

Asshiddiqie, Jimly. Pengantar Ilmu Hukum Tata Negara, Jakarta: Rajawali Pers, 2010.

Buang, Ahmad Hidayat dan M. Cholil Nafis. "Peranan MUI dan Metodologi Istinbat Fatwa dalam Undang-Undang Perbankan Syariah di Indonesia (The Role of MUI and Methodology of Istinbat Fatwa in Indonesian Banking Law)", Jurnal Pengurusan, Vol. 35, No. 1, 2012.

DSN-MUI Nomor 05/DSN MUI/ IV/ 2000 tentang jual beli salam, lihat http://www. dsnmui.or.id/index.php?mact=News,cntnt01, detail,0\&cntnt01articleid=101\&cntnt01origi $\mathrm{d}=66 \&$ cntnt01detailtemplate $=$ Fatwa\&cntnt 0 1 returnid=59, diunduh pada 6 Agustus 2015.

Gayo, Ahyar Ari dan Ade Irawan Taufik. Kedudukan Fatwa DSN-MUI Dalam Mendorong Perkembangan Bisnis Perankan Syariah (Perspektif Hukum Perbankan Syariah), Jakarta: Rechts Vinding Media Pembinaan Hukum Nasional, 2012, Vol. 1 Nomor 2, Agustus 2012.

Himpunan Fatwa Majelis Ulama Indonesia sejak 1975, Jakarta: Erlangga, 2011.

Juhaya, S. Pradja. Ekonomi Syariah, Bandung: CV Pustaka Setia, 2012.

Kamus Besar Bahasa Indonesia, edisi ke-3, cetakan I, Jakarta: Balai Pustaka 2001.

Keputusan Dewan Syariah Nasional Majelis Ulama Indonesia Nomor 01 Tahun 2009 tentang Pedoman Dasar Dewan Syaria Nasional-Majelis Ulama Indonesia (PD DSN-MUI).

Khaeruman, Badri. Hukum Islam Dalam Perubahan Sosial, Bandung: Pustaka Setia, 2010

Mahkamah Agung RI, Pedoman Pelaksanaan Tugas dan Administrasi Peradilan Agama Buku II, Jakarta: Direktorat Jendral Badan Peradilan Agama, 2013.

Mas'adi, Ghufron A. Figh Muamalah Kontekstual, Jakarta: PT Raja Grafindo Persada, 2002.
Mustofa, Imam. Ijtihad Kontemporer Menuju Fiqh Kontekstual, Jakarta: Rajawali Pers, 2013.

Nafis, M. Cholil. Teori Hukum Ekonomi Syariah, Jakarta: UI Pers, 2011.

Pedoman Penyelenggaraan Organisais Majelis Ulama Indonesia, Jakarta: Sekretariat Majelis Ulama Indonesia Pusat, 2011.

Pusat Pengkajian Hukum Islam dan Masyarakat Madani (PPHIMM), Kompilasi Hukum Ekonomi Syariah, Jakarta: Kencana, 2009.

Riadi, M. Erfan. "Kedudukan Fatwa Ditinjau dari Hukum Islam dan Hukum Positif (Analisis Yuridis Normatif)", Jurnal Ulumuddin, Vol. VI, Tahun IV, Januari Juni 2010.

Ridwan, Murtadho. Analisis Fatwa MUI Tentang Asuransi Syariah Dan Penyerapannya Ke Dalam Peraturan Perundang-Undangan dalam buku yang bertajuk Fatwa Majelis Ulama Indonesia (MUI) Dalam Perspektif Hukum Dan Perundang-Undangan, Jakarta: Puslitbang Lektur dan Khazanah Keagamaan Badan Litbang Dan Diklat Kementerian Agama RI, 2012.

Rusli, Tipologi Fatwa di Era Modern: dari Offline ke Online, Palu: Hunafa: Jurnal Studia Islamika, 2011, Vol. 8, No. 2, Desember 2011.

Sholihin, Ahmad Ifham. Pedoman Umum Lembaga Keuangan Syariah, Jakarta: Gramedia Pustaka Utama, 2010.

Simonangkir dkk. Kamus Hukum, Jakarta: Sinar Grafika, 2009.

Sudarsono, Heri. Bank dan Lembaga Keuangan Syariah: Deskripsi dan Ilustrasi, Yogyakarta: Ekonisia, cetakan kedua, 2004.

Sula, Muhammad Syakir. Asuransi Syariah, Jakarta: Gema Insani Press, 2004.

Syafe'i, Rachmat. Figh Muamalah, Bandung: Pustaka Setia, 2001.

Syarifudin, Amir. Ushul Figh Jilid 2, Jakarta: Kencana, 2009.

Uman, Khairul dan A. Ahyar Aminudin. Ushul Figh II, Bandung: Pustaka Setia, 1998. 
Umar, Husein. Metode Artikel Untuk Skripsi dan Tesis Bisnis, Jakarta: PT.Raja Grafindo Persada 2011.

Undang-Undang No. 12 Tahun 2011.

Undang-Undang Nomor 10 Tahun 1998 tentang Perbankan.

Undang-undang Nomor 21 Tahun 2008 Tentang Perbankan Syariah.
YS Caniago, Amran. Kamus Lengkap Bahasa Imdonesia (Dilengkapi dengan singkatansingkatan), Bandung: CV Pustaka Setia, 1997.

Zuriah, Nurul. Metodologi Artikel Sosial danPendidikan Teori-Aplikasi, Jakarta: Bumi Aksara, 2009. 